DOI 10.15290/oolscprepi.2018.42

\title{
THE REASONING ABOUT EVIDENCE IN TAX MATTERS ${ }^{1}$
}

\author{
JOZEF SÁBO
}

\begin{abstract}
The article deals with reasoning about evidence in tax matters. The Author of the article analyses common errors in comprehending of evidence by tax administrators. The Author classifies these errors into two types: incorrect evaluation of burden of proof and incorrect allocation of the burden of proof. The main goal of the article is to examine, how to assess the burden of proof in tax matters. The article examines the rational limitation of the scope of evidence burden that should be respected by tax administrator in tax proceedings. Moreover, the article advocates the application of a rule in dubio mitius in respect to reasoning about evidence.
\end{abstract}

\section{Keywords}

Tax law; errors in reasoning about evidence; burden of proof in tax matters

JEL Classification: D63, K34, K40

\section{Introduction}

Obtaining of evidence is typically divided into three phases: seeking of evidence, taking of evidence and evaluation of evidence (Záhora, 2013:20). Strict division of collection of evidence into these distinct phases is often not needed because of taking evidence and evaluation of evidence often overlap. Therefore we can talk

1 This article presents a partial output of grant project VEGA no. APVV-16-0160 "Tax evasions and tax frauds and legal possibilities of its prevention (by institutes of tax law, commercial law, and criminal law)".

2 Doctor, works as a full-time researcher - post-doctoral in the Department of Financial Law, Tax Law and Economics at the Faculty of Law - Pavol Jozef Šafárik University in Košice. He has participated in scientific research also within projects implementation VEGA č. 1/0375/15, VEGA č. 1/1170/12 and VVGS č. 2013-108. In 2016 he published the scientific monograph on international tax avoidance and tax evasion: "Medzinárodné daňové úniky a metódy ich predchádzania. (International tax avoidance and methods to combat aggressive tax planning)". Contact email: jozef.sabo@upjs.sk. 
about the collection of evidence on one hand and the comprehending of evidence on the other (as a term for taking of evidence and evaluation of evidence).

Collection of evidence includes every activity of the tax administrator which seeks to obtain the source of information (source of evidence) for tax administration. Term comprehending of evidence means every procedural activity which seeks to extract information from the source of evidence, to record information in the legal form and to transform all recorded information into the decision on factual circumstances of a tax case (Babčák, 2015). The factual findings of the tax administrator are recorded in minutes and official records (sect. 19 of Act no. 563/2009 on Tax Administration and on amendments and supplements to certain laws, hereinafter as "Tax Code") or in obiter dictum of a decision (sect. 65/5 of the Tax Code).

We can, therefore, classify errors in the collection of evidence during tax administration into two categories: errors in the collection of evidence and errors in comprehending of evidence. Error in the collection of evidence occurs in the situation when tax administrator does not obtain sufficient sources of evidence for the decision. Errors in comprehending of evidence include two types of errors: incorrect evaluation of burden of proof and incorrect allocation of the burden of proof.

However, various types of errors concerning evidence often do not occur separately. Incorrect evaluation of burden of proof may lead to error in the collection of pieces of evidence. For example, if tax administrators think that burden of proof is on the taxpayer than tax administrators do not obtain evidence about actions of the taxpayer establishing the case for abuse of tax law, although taxpayer provides all evidence needed to prove that taxable transaction actually happened. Therefore tax administrators often make mistake in the assessment of the taxable transaction and incorrectly rule that taxable transaction did not happen. This decision of tax administrators may be declared unlawful by the court. In this stage, the tax administrators cannot repeat tax audit and opportunity for obtaining evidence related to abuse of tax law/ tax evasion is lost afterward.

In the article, we focus our attention on the errors of comprehending of evidence. The main goal of the article is to examine, how to assess the burden of proof in tax matters. In the research presented in this article method of logical analysis, deduction and method of logical synthesis are used. Our conclusions are based primarily on the grammatical and systematic interpretation of legal provisions. 


\section{Incorrect Evaluation of Burden of Proof}

\subsection{Burden of Proof in Tax Administration}

As we mentioned earlier incorrect evaluation of burden of proof constitutes an error in comprehending of evidence. Generally, term objective burden of proof means "a rule which prescribes how the state authority / judge should decide on the merits if the relevant fact of the case is not proved and therefore a state of objective uncertainty occurs" (Macur, 1995: 13). General rule for allocation of burden of proof in tax matter between tax administrator and tax person participating at the tax administration (hereafter "taxpayer") contains section 24 of the Tax Code: taxable payer shall prove facts which have an impact on correct tax determination and facts which it is obliged to state in its tax return or other filings which it is obliged to submit pursuant to special regulations and credibility, correctness and completeness of records which it is obliged to keep (sect. 24/1/a and 24/1/c of Tax Code). On the other hand, tax administrator shall prove (sect. 24/3 of Tax Code) facts regarding actions performed towards the taxable payer which are decisive for correct tax inquiry.

Moreover, the taxpayer shall prove facts which it has been asked to prove by the tax administrator in the course of a tax audit or tax proceedings (sect. 24/1/b of Tax Code). In that regard, the tax administrator has the competence to create the burden of evidence for the tax payer. However such competence of tax administrator is limited by actual circumstances of the tax matter. Therefore tax administrator can only create the burden of evidence concerning facts directly stated by taxpayer (or facts/statements which are included in taxpayers' records) (Kobík, Šperl, 2005: 15).

Notwithstanding such limitation, we recognize further limits in the scope of the burden of evidence in tax matters. The course of taxable event / transaction produces the only certain number of material evidence. Therefore taxpayer is always limited in the scope of possible evidence according to the particular circumstances of taxable event(s) (which is under consideration during tax proceedings). The taxpayer cannot provide more material evidence than actually exists (was created) in a tax matter. Therefore even in cases when the burden of proof is on the taxpayer, there are specific/rational limits for the burden of evidence in each particular tax case.

The assessment of burden of proof depends on the assessment of limits of the burden of evidence. It seems that burden of proof is not the static rule (Svoboda, 2009: 38), but the burden of proof has certain "weight" according to circumstances of the actual tax matter. Tax administrators often do not consider sufficient the evidence that is provided by the taxpayer to prove facts of the tax matter, even in cases when the taxpayer had exhausted / fulfilled his burden of evidence within the 
rational limit. Such incorrect evaluation of burden of proof by tax administrator consequently results in wrong refusal to recognize the tax right of the taxpayer.

We are of the opinion that such evaluation of tax burden is erroneous. In that regard, we may point to the wording of section 24/2 of Tax Code, which states that Tax administrator shall lead the collection of evidence, while it shall make sure that facts necessary for tax administration purposes are identified in their possible entirety, and it shall not be only bound by proposals of taxable entities. From stated legal norm results that evaluation of pieces of evidence always follows the actual circumstances of the tax case. Also, word "possible" implies that collection and evaluation of evidence cannot lead to the situation in which then the taxpayer is obliged to prove facts beyond reasonable possibility. This conclusion is the generalization of the negative theory of evidence, which states that something that did not happen cannot be supported by evidence (because evidence of such event just does not exist). Therefore evidence that does not exist cannot prove something that actually happened. Therefore, proper evaluation of burden of proof always consists of the assignment of "weight" to the burden of proof in particular matter according to types and the possible number of evidence that may/should exist in particular tax case.

\subsection{Different Categories of Evidence}

Tax law (as an independent legal branch) prescribes for tax entities certain evidence that should create/ have to provide to prove facts of the tax case. Such evidence is primarily in the form of records that tax entities should keep. With this in mind, we can classify the source of evidence in tax matters into four categories:

a) sources of information prescribed by law: tax entities have the duty to collect/ create certain sources of information for example accounting document, invoices etc. In case of the tax audit, tax entities are obliged to provide these sources of information to tax administrator as evidence in tax proceedings,

b) sources of information that are usually/ typically created during the business transaction in the normal course of business activities (written contracts etc.). These are not evidenced in the actual tax case but serves as examples of evidence that might occur in connection with the certain business transaction. Tax administration according to his experience can rationally expect certain sources of information created in similar business operations,

c) sources of information that should have been created in the actual tax case,

d) sources of information that taxpayer actually provides as evidence to tax administrator. 
Every absence of the certain source of information that is relevant for decision in tax matter creates the evidential gap that should be addressed by tax administrator in the phase of comprehending of evidence. Even if the sources of information are provided to tax administrator thus forming an evidence of tax case, they may have certain defects. First types of defects are defects in formal requirements. Second types of defects are defects in credibility. Defects in credibility occur when information that follows from the certain source of evidence contradicts information obtained from other sources of evidence. Every defect in the credibility of evidence should be addressed by the tax administrator in the phase of comprehending of evidence.

In case of sources of information falling into category c) - for example contracts, any defect in formal requirements: for example contracts which should be in writing are concluded only orally, might constitute defects in credibility as well. But it is not always the case; defects of formal requirements of evidence do not necessarily constitute the defect in credibility. If the evidence has the defect in formal requirements but it is credible and offers clear information about transaction/ legal relation in question, the tax administrator should not disregard such evidence as invalid (e.g. evidence that is not capable to prove information that such source of evidence should incorporate). This is also true of evidence in category a) e.g. sources of evidence prescribed by tax law (for example invoice).

The situation is different when the taxpayer does not provide prescribed sources of information falling into category a): therefore by his own omission creates the evidential gap. Tax entities have duty prescribed by law to keep track/create sources of information for certain business activities. If the taxpayer does not fulfill this obligation, tax administrator can refuse to recognize some of tax right of the taxpayer.

Often tax administrator expects from the taxpayer to provide certain types of evidence (according to his experience from similar tax matters): for example, if the taxpayer obtains goods, tax administrator may expect that taxpayer has the warehouse for storing goods. Difference between evidence expected by tax administrator due to his experience and evidence that is provided by the taxpayer is an example of contradiction between evidence falling into category b) and evidence falling into category d). However, it is important to mention that this contradiction does not constitute an evidential gap, but serves merely as an indication of potential misconduct on part of the taxpayer. The indication is not evidence, therefore, could not directly prove any fact of the tax matter. If the non-contact taxpayer (e.g. the taxpayer who does not collaborate with tax authority) was one of the taxpayers in the chain of taxable transactions, it indicates that other taxpayers might have participated in tax fraud. But such suspicion cannot automatically lead to the 
conclusion that other taxpayer in fact knowingly participated in tax fraud. Every suspicion of tax administrator must be proved by corresponding evidence: but in that case the burden of proof shifts to the tax administrator.

The most important is a connection between sources of information falling into category c) and sources of evidence falling into category d). Unlike the previous situation, these sources of information are not only "typical" or "possible" but must actually exist for the transaction to ever happen. To know which kind of sources of information should have existed in a certain tax case, the tax administrator must examine actual circumstances of the transaction/event. These circumstances cannot be inferred only from "formal" evidence e.g. from accounting records or tax returns of the taxpayer. Tax administrator should as soon as possible obtain testimony from the taxpayer about actual circumstances of the transaction.

Tax administrator can infer from the circumstance of the business transaction described by the taxpayer in his testimony or in testimonies of other persons working for the taxpayer what sources of information were created during this transaction. For example, if the taxpayer testifies that the goods were dispatched by shipping company then such transaction should have created sources of information in form of contract with the shipping company, contract with the buyer of goods, testimonies of persons acting for shipping company and testimony of persons acting for buyers. Subsequently, tax administrator can ask from the taxpayer to provide these sources of information as evidence for tax audit / tax proceedings. If the taxpayer fails to provide evidence to support his statements about actual circumstances of the business transaction, tax administrator should conclude that the taxpayer does not carry his burden of proof.

Therefore is of vital importance for tax administrators to differentiate between evidence that should have been created (according to the common course of events) and sources of information that according to own statements of the taxpayer were actually created in course of the transaction.

To know actual circumstances of the transaction enables the tax administrator to anticipate rational limit of the evidential burden of the taxpayer. If the taxpayer provides as evidence all sources of information that should have been created by business transaction, the tax administrator should not ask the taxpayer for further evidence. Also, tax administrator cannot ask the taxpayer to provide negative facts. For example to prove, that the taxpayer did not know about tax fraud happening along the chain of transaction.

If taxpayer fulfills his evidential burden then he carries its burden of proof. If suspicions of tax administrator about the misconduct of taxpayer persist then tax 
burden is on the tax administrator to prove that taxpayer participated in tax evasion or acted contrary to the tax legislation otherwise.

\section{Incorrect Allocation of Burden of Proof}

As we mentioned earlier, the term burden of proof stands for rule prescribing how to decide in objective uncertainty about factual circumstances of the case. The situation in reasoning about evidence when this objective uncertainty occurs is called non licet. If evidential reasoning in case reaches non licet stage then the judge should decide against the party/ subject who does not carry the burden of proof (Macur, 1995: 13). This "classical" view on the burden of proof seems not be appropriate in tax matters.

We are of the opinion that majority of evidence in tax matters are formal by nature. Under "formal" we mean sources of information that are predominately in written form and constitute indirect evidence about transactions / taxable events. For example, formal evidence of taxable transaction includes contracts, invoices, and other written documents. At the same time, tax entities often bear the burden of proof about material (e.g. actual) circumstances of the tax case and they should prove that certain transaction really happened.

This may be problematic, because written documents may offer only indirect evidence about past events. If some of these documents have defects (especially defects in credibility) also the reliability of testimony given by taxpayers is questioned. Thus the taxpayers often lack any direct evidence to sustain his claims about nature of the taxable transaction. This is especially the problem for taxpayers in tax matters concerning indirect taxes.

In aforementioned circumstances, the tax administrators often rule that taxpayers fail to prove that taxable transaction actually happened. We consider similar reasoning about evidence incorrect. This constitutes incorrect reasoning about evidence and it is an error in the allocation of the burden of proof.

We are of the opinion that formal evidence should be sufficient to prove material circumstances of the transaction in most cases. This conclusion is based on the rational limit of evidence burden determined by actual circumstances of the past event/ transaction. Reason for this is the fact that majority of the business transaction does not produce any other sources of evidence besides written documents and testimony of the taxpayer.

Tax administrators often do not accept written evidence as sufficient evidence for actual material circumstances of the tax matter. Generally, a defect in the 
credibility of evidence cannot serve as justification for the similar conclusion. Only exceptionally in situations when defects in the credibility of evidence are severe and reach across multiple sources of information tax administrators can conclude that taxable transaction almost certainly did not happen. But generally, when the indication of misconduct of taxpayer exists in the tax case, the burden of proof shifts to tax administration to prove that the taxpayer acted in breach of tax norms. Therefore the burden of proof in tax matters is not static but it is similar to the concept of tactical burden of proof (Walton, 2015: 9; Kazazi, 1996: 24).

Moreover, we think that the rule in dubio pro mitius (Melzer, 2009) should be used also in the assessment of allocation of the burden of proof. This opinion is based on the principle of legality in tax matters (Bujňáková, 2006: 162). We define the rule in dubio pro mitius in respect to reasoning about evidence as following: if defects in credibility of evidence might lead to negative factual findings (e.g. conclusion that something did not happen) or alternatively might cause shift of burden of proof towards tax administrator to prove misconduct on the part of the taxpayer, the burden of proof should shifts towards tax administrator, except in situations when defects in credibility of evidence are severe and reach across multiple sources of information in tax case.

\section{Conclusions}

In the article, we analyzed errors in the evaluation of evidence. Our main concern was errors in comprehending of evidence. We analyzed two variants of these errors: incorrect evaluation of burden of proof and incorrect allocation of the burden of proof.

Our main concern was an allocation of the burden of proof in tax matters and scope of evidential burden. We propose that there is the rational limit in the scope of evidence burden that should be respected by tax administrator in tax proceedings. Moreover, we advocate the application of the rule in dubio pro mitius in respect to reasoning about evidence.

We recognize that it might be very hard for tax administrators to prove situations of tax fraud or tax evasion. Nevertheless, correct assessment of allocation of the burden of proof is essential for tax administration because it is a part of the principle of legality and legal certainty in tax matters. 


\section{References}

Babčák, V.: Daňové právo na Slovensku (Tax law in Slovakia), Bratislava: EPOS, 2015.

Bujňáková, M.: Princípy a zásady v daňovom práve (Principles in Tax law), in: Aktuálne otázky práva (Current questions of Law), Košice: Univerzita P.J. Šafárika v Košiciach, 2006.

Kazaki, M.: Burden of Proof and Related Issues: A Study on Evidence Before International Tribunals, Hague: Kluwer Law International, 1996.

Kobík, J., Šperl, J.: Dokazováni v daňovém řízení (Collection of evidence in tax proceedings), Praha: ASPI., 2005.

Macur, J.: Dukazní břemeno v civilním soudním řízení (Burden of proof in civil proceedings), Brno: Masarykova Univerzita, 1995

Melzer, F.: Metodologie nalézání práva. Úvod do právní argumentace (Methodology of finding the Law. Introduction to the legal argumentation), Praha: C.H. Beck, 2009.

Svoboda, K.: Dokazování (Collection of evidence), Praha: Wolter-Kluwer, 2009.

Walton, D.: Burden of Proof, Presumption and Argumentation, New York: Cambridge University Press, 2014.

Záhora, J. et al.: Dokazovanie v trestnom konaní (Collection of evidence in criminal proceedings 1st. ed.), Praha: Leges, 2013.

SK: Act no. 563/2009 Coll. on Tax Administration (Tax Procedure Code) and on amendments and supplements to certain laws. 